\title{
The effect of enzyme supplementation of triticale-barley feeds on fattening performance of turkeys
}

\author{
D. Mikulski, J. Jankowski, A. Faruga and Marzena Mikulska
}

\author{
Department of Poultry Science, \\ Olsztyn University of Agriculture and Technology \\ 10-718 Olsztyn 5, Poland
}

(Received 24 February 1997; accepted 19 August 1997)

\begin{abstract}
The study was carried out on 456 one-day old BUT-9 tom poults divided into 4 groups ( 3 replicates $x 38$ poults per group) fattened until the age of 154 days.

The control group was fed a wheat-maize fecd. These cereals were replaced by triticale and barley in the experimental diets. Mixture 1 was given without enzymatic supplements, feeds 2 and 3 contained different enzyme preparations. Less soya oil was added to enzyme-supplemented feeds, on the assumption that the addition of enzymes can increase the $\Lambda \mathrm{MEN}$ of triticale and wheat by $6 \%$, of barley by $10 \%$.

Body weight and feed utilization indexes, nutrient digestibility and dressing percentage were similar in all of the groups. Enzyme-supplemented feeds were more economical in comparison with the control triticalc-barley diets (by 5.0-7.5\%) and wheat-maize diets (by $8.5-11.0 \%$ ).
\end{abstract}

KEY WORDS: turkeys, feeding, enzymes

\section{INTRODUCTION}

The polysaccharides found in the endosperm of kernels, i.e. $\beta$-glucans and arabinoxylanes and pectins, limit the nutritive value of cereals by increasing the viscosity of intestinal contents, making the faeces excessivcly moist and viscous, and causing diarrhoea in birds (Brenes et al., 1993; Ferket,1993; Jeroch et

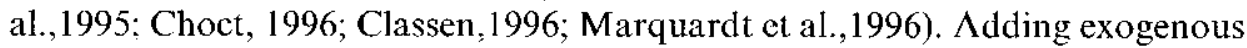
enzymes such as $\beta$-glucanase, pentosanase and cellulase can improve the efficiency of ccreal diets for poultry by hydrolyzing non-starch polysaccharides, 
improving the digestibility of nutricnts and increasing the energy value of the diet.

The effects of enzymes have been studied mainly on feeds containing substantial amounts of barley or rye, and better weight gains and feed utilization were achieved (Rotter et al., 1990; Mohammed, 1995; Al Bustary, 1996; Kaoma et al., 1996). In the case of feeds containing triticale or wheat, the addition of enzymes also had favourable effects (Salobir et al., 1994; Richter and Müller, 1995).

Enzymes are added to improve the economy of feeding, but their effectiveness depends on the type and amount of enzymes as well as on the substrate (Muramatsu et al., 1992; Brenes ct al., 1993; Jcroch et al., 1995; Mohammed, 1995; Al Bustary, 1996; Faruga et al., 1996; Kaoma et al., 1996; Marquardt et al., 1996).

The objective of this study was to determine the effectiveness of two enzyme preparations as additives to feedstuffs containing substantial amounts of triticale and barley used in the fattening of meat turkeys.

\section{MATERIAL AND METHODS}

The experiments were carried out at the State Turkey Evaluation Station of the Olsztyn University of Agriculture and Technology in Olsztyn from $\Lambda$ pril to October 1996. Four hundred and fifty-six one-day-old tom poults of the BUT-9 hybrid were used in the experiment. Thirty-eight were randomly assigned to 12 pens ( 3 replicate pens) to each of 4 feeding groups.

The feed mixtures (Tables 1 and 2 ) for the toms in the control group contained wheat and maize as the main cereals, while groups 1,2 , and 3 received triticalc and barley. The feed given to group 2 contained an enzyme preparation denoted as $A$ in an amount supplying 250 units of $\beta$-glucanase and 375 units of xylanase, while the group 3 feed was supplemented with enzyme preparation $\mathbf{B}$ in an amount supplying 3250 units of $\beta$-glucanase, 2250 units of xylanase and 1000 units of cellulase per kilogram of feed. The enzymatic activities of the enzyme preparations are given in agreement with the information provided by the manufacturer. The energy value of all of the feed mixtures was balanced by adding soya oil. The energy calculations for groups 2 and 3 accounted for higher energy for wheat and triticale $(6 \%)$ and barley $(10 \%)$, in the case of the enzyme-supplemented diets. The initial energy value of ccreals was based on the Nutrient Requirements of Poultry (1993).

Fattening was continued until 154 days ( 22 weeks) under standard conditions and in accordance with the recommendations of animal husbandry (Faruga and Jankowski, 1996). Granulated feeds were provided ad libitum according to 


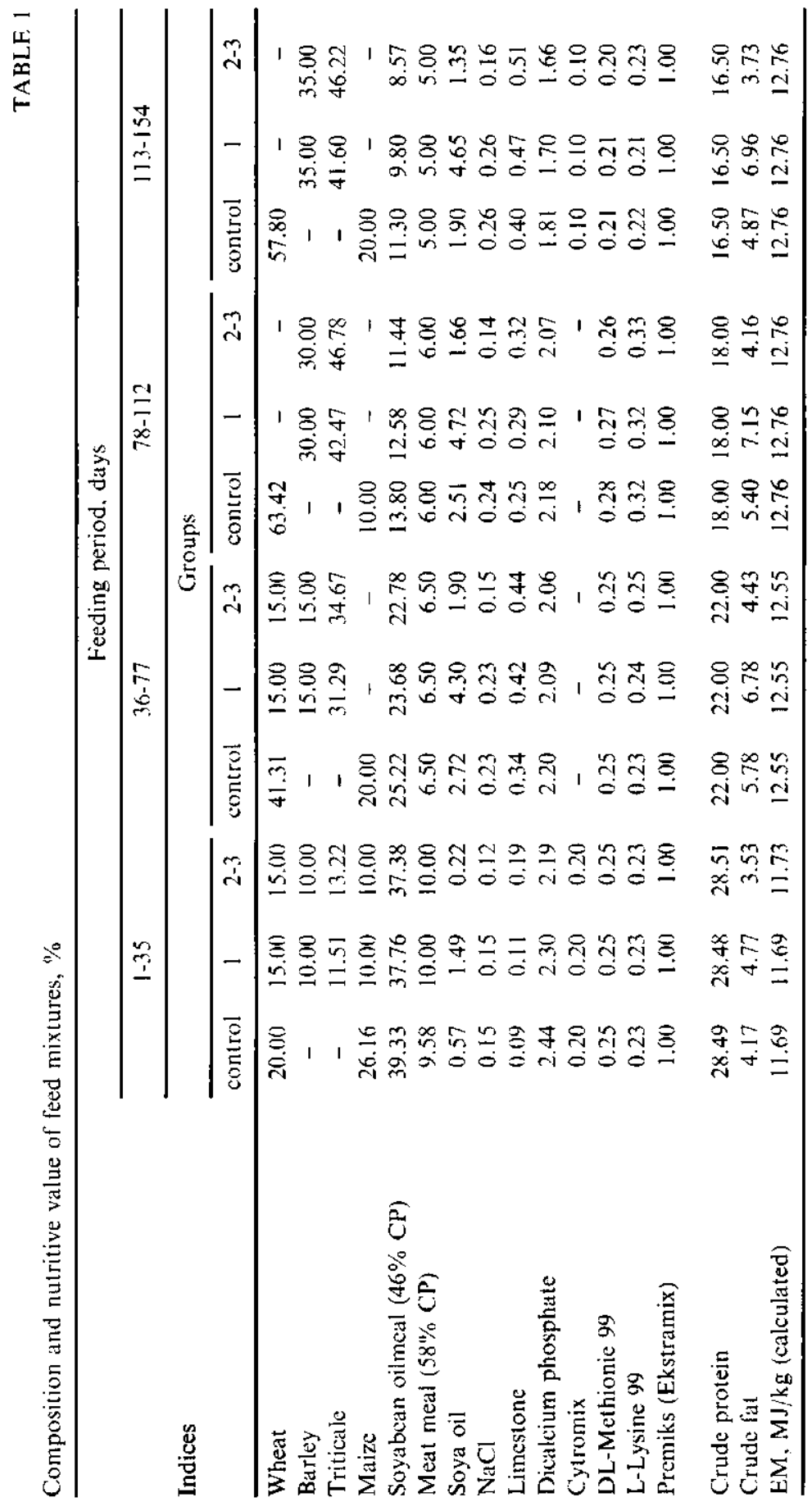


TABLE 2

Content of some amino acids, vitamins and minerals $/ 1 \mathrm{~kg}$ feed mixture

\begin{tabular}{|c|c|c|c|c|}
\hline \multirow[b]{2}{*}{ Components } & \multicolumn{4}{|c|}{ Feeding period,days } \\
\hline & $1-35$ & $36-77$ & $78-112$ & $113-154$ \\
\hline Methionine & 0.66 & 0.57 & 0.54 & 0.46 \\
\hline Methionine - cystine & 1.10 & 0.94 & 0.86 & 0.77 \\
\hline Lysine & 1.78 & 1.35 & 1.15 & 0.95 \\
\hline Arginine & 1.94 & 1.42 & 1.09 & 0.97 \\
\hline Tryptophan & 0.31 & 0.24 & 0.19 & 0.17 \\
\hline Vitamin $\mathrm{A}, \mathrm{IU}$ & 15000 & 13000 & 12000 & 12000 \\
\hline Vitamin $\mathrm{D}_{3}, \mathrm{IU}$ & 4000 & 3000 & 2500 & 2500 \\
\hline Vitamin E, mg & 40 & 35 & 30 & 30 \\
\hline Vitamin $\mathrm{K}_{3}, \mathrm{mg}$ & 2.5 & 2 & 2 & 2 \\
\hline Vitamin $\mathbf{B}_{1}, \mathrm{mg}$ & 2.5 & 2 & 2 & 2 \\
\hline Vitamin $\mathrm{B}_{\hat{\imath}}, \mathrm{mg}$ & 10 & 8 & 6 & 6 \\
\hline Vitamin $\mathrm{B}_{6}, \mathrm{mg}$ & 5 & 3.5 & 3 & 3 \\
\hline Niacin, mg & 70 & 65 & 65 & 65 \\
\hline Pantotenic acid, mg & 20 & 18 & 15 & 15 \\
\hline Folic acid, mg & 2 & 1.5 & 1.3 & 1.3 \\
\hline Biotin, mg & 0.3 & 0.2 & 0.15 & 0.15 \\
\hline Choline, $\mathrm{mg}$ & 600 & 400 & 300 & 300 \\
\hline $\mathrm{Ca}, \mathrm{g}$ & 1.4 & 1.2 & 1.1 & 1.0 \\
\hline P (available), $\mathrm{g}$ & 0.77 & 0.65 & 0.65 & 0.57 \\
\hline $\mathrm{Mn}, \mathrm{mg}$ & 120 & 100 & 100 & 100 \\
\hline $\mathrm{Zn}, \mathrm{mg}$ & 90 & 80 & 70 & 70 \\
\hline $\mathrm{Fe}, \mathrm{mg}$ & 60 & 50 & 45 & 45 \\
\hline $\mathrm{Cu}, \mathrm{mg}$ & 10 & 8 & 7 & 7 \\
\hline $\mathrm{J}, \mathrm{mg}$ & 1 & 0.8 & 0.7 & 0.7 \\
\hline $\mathrm{Se}, \mathrm{mg}$ & 0.3 & 0.3 & 0.3 & 0.3 \\
\hline
\end{tabular}

from 1 to 77 days cocidiostatic Diclazuril (qmg) and growth stimulator Flawofosfolipol (5 mg) were added

a program entailing 4 feeding stages: starter (1-35 days), grower 1 (36-77 days), grower 2 (78-112 days) and finisher (113-154 days). All of the birds were weighed at the ages of $35,56,77$ and 154 days, group fecd intake was measured weekly. Mortality and culling were ongoing, and the causes were also recorded.

At the age of 10 weeks, 4 birds from each group were placed in individual metabolic cages and fed grower mixture no. 1 ad libitum. The amount of consumed feed and excrement were registered for five successive days. Faecal nitrogen was distinguished from urinary nitrogen by the method of Ekman et al. (1949). The content of basic nutrients was determined in the feed mixtues and faeces by conventional methods, the content of structural carbohydrates was determined according to Van Soest and Wine (1967) using a Tecator AB Fibertec 
$M$ apparatus and the gross energy content in a $\mathrm{KL}-10$ calorimeter. The apparent digestibility of nutrients, neutral detergent fibre (NDF), acid detergent fibre (ADF), and hemicellulose were determined on the basis of the obtained results.

The Fattening Efficiency Index (FEI) was calculated using the following formula:

$$
\text { FEI }=\frac{(\text { sum of final body weight })^{2} \times 10000}{\text { days of fattening } x \text { number of birds } x \text { feed consumption }}
$$

At the end of the fattening period, 8 toms from each group were selected, fasted $(12 \mathrm{~h})$, slaughtered, and carcass dressing analysis performed.

The results were subjected to statistical analysis using the STAT 1 program and variance analysis, followed by Duncan's multiple range test.

\section{DISCUSSION}

When balancing the energy value (AME $)$ of the feed mixtures, it was taken into account studies reported by Jeroch et al. (1995) and Marquardt et al. (1996), were the addition of enzymes increased the energy value of feeds. This increase was accepted as $6 \%$ in the case of wheat and triticale, and $10 \%$ in the case of barley, and the amount of soya oil added to the enzyme-supplemented triticalebarley mixtures was reduced accordingly.

No differences were found among groups with respect to the crude protein, NDF and ADF digestibilities of grower 1 feeds (Table 3). The fat in the triticale-barley mixtures was not digested as well as that from the wheat-maize mixtures (-2.6-3.6\%). In the case of the wheat-barley supplemented with enzyme preparation $\mathrm{B}$, the digestibility of hemicellulose and nitrogen retention decreased $(P \leqslant 0.05)$, the reason for which was not obvious. The differences in the digestibility of some components and structural carbohydrates, although statistically significant, did not result in distinct changes in the results of fattening. In other studies (Muramatsu et al., 1992; Salobir et al., 1994; Kaoma et al., 1996; Marquardt et al., 1996) increased digestibility of dietary nutrients was usually found as the result of adding exogenous enzymes. This applies in particular to fat, protein and nitrogen retention, and in some cases, to crude fibre as well.

The assumption made in this study that adding exogenous enzymes, increased the $\mathrm{AME}_{\mathrm{N}}$ of wheat and triticale by $6 \%$ and barley by $10 \%$, was confirmed by the balance studies on turkeys. The energy values $\left(\Lambda \mathrm{ME}_{\mathrm{y}}\right)$ of feeds 1 to 3 were similar (12.22-12.40 MJ/kg), however, in comparison with the control feed they 
TABELA 3

Balance experiment

\begin{tabular}{|c|c|c|c|c|c|}
\hline \multirow{2}{*}{ Indices } & \multicolumn{4}{|c|}{ Groups } & \multirow{2}{*}{ SEM } \\
\hline & control & 1 & 2 & 3 & \\
\hline \multicolumn{6}{|l|}{ Digestibility coefficients, \% } \\
\hline crude protein & 82.9 & 83.0 & 82.1 & 82.1 & 0.228 \\
\hline crude lat & $64.7^{:}$ & $63.0^{\mathrm{b}}$ & $63.0^{\mathrm{b}}$ & $62.4^{\mathrm{h}}$ & 0.477 \\
\hline NDF & 43.6 & 42.3 & 43.0 & 41.3 & 0.747 \\
\hline ADF & 7.7 & 9.5 & 9.8 & 11.0 & 1.186 \\
\hline hemicellulose & $58.3^{a}$ & $59.5^{\mathrm{A} a}$ & $58.9^{a}$ & $56.2^{\mathrm{Bb}}$ & 0.545 \\
\hline $\mathrm{N}$ retention, \% of $\mathrm{N}$ intake & $47.9^{\prime \prime}$ & $48.9^{: 1}$ & $47.6^{\mathrm{ab}}$ & $46.5^{h}$ & 0.666 \\
\hline $\mathrm{AME}_{\mathrm{N}}, \mathrm{MJ} / \mathrm{kg}^{*}$ & $12.63^{\mathrm{At}}$ & $12.35^{\mathrm{ABb}}$ & $12.22^{\mathrm{B}}$ & $12.4^{\mathrm{ABb}}$ & 0.271 \\
\hline $\mathrm{AME}_{\mathrm{N}} / \mathrm{GE}, \%$ & $70.15^{\prime \prime}$ & $67.08^{\prime}$ & $68.45^{\mathrm{b}}$ & $70.13^{\prime \prime}$ & 0.413 \\
\hline Droppings DM, $\%$ & 18.6 & 19.7 & 17.6 & 18.4 & 0.732 \\
\hline
\end{tabular}

$\mathrm{a}, \mathrm{b}, \mathrm{c}-\mathrm{P} \leqslant 0.05$

$A, B-P \leqslant 0.01$

were about $1.8-3.2 \%$ lower $(\mathrm{P}<0.05)$. Gross energy utilization of feed 3 and the control feed were about $70.1 \%$, while that of feeds 1 and 2 was lower by 4.3 and $2.3 \%$, respectively $(\mathrm{P}<0.05)$.

The addition of enzymes to the feeds did not have the expected effects of reducing excrement moisture content (Table 3), as reported by other authors (Salobir et al., 1994; NI Bustary, 1996; Marquardt et al., 1996).

The results of rattening tom turkeys are presented in Table 4. Up to day 56 the birds from group 3 (preparation $B$ ) showed poorer weight gains $(P<0.05)$. Later (at 77 and 112 days of age), the body weights of toms in all groups were similar. At the completion of fattening (154 days) the body weights of the toms were not significantly different, ranging from $16.59 \mathrm{~kg}$ (group 3) to 17.02 (control group). A similar relationship was found for feed utilization per kilogram body weight (Table 4). In none of the studied periods was there any significant difference in this trait among the groups. The body weights of 22 -weck-old toms and feed utilization $(2.82-2.93 \mathrm{~kg} / \mathrm{kg})$ in fattening did nol differ significantly from the optimal values given for moderately heavy BUT 9 tom turkeys (BUT 9 - Performance goals, 3rd Edition, British United Turkeys).

The addition of either enzyme preparations lowered the cost of feed used per kilogram weight gain of the tom turkeys by $7.5-11.0 \%$ in comparison with the control group and by $5.0-8.5 \%$ in comparison with the group fed the triticale-barley diet not supplemented with enzymes. 
TABLE 4

Performance of turkeys

\begin{tabular}{|c|c|c|c|c|c|}
\hline \multirow{2}{*}{ Indices } & \multicolumn{4}{|c|}{ Groups } & \multirow{2}{*}{ SEM } \\
\hline & control & 1 & 2 & 3 & \\
\hline \multicolumn{6}{|l|}{ Body weight, $\mathrm{kg}$} \\
\hline at day: 35 & $1.02^{\mathrm{A}}$ & $1.04^{\mathrm{A}}$ & $1.03^{\mathrm{A}}$ & $0.96^{\mathrm{B}}$ & 0.012 \\
\hline 56 & $2.95^{\wedge \mathrm{Ba}}$ & $2.99^{\wedge a}$ & $2.93^{\mathrm{ab}}$ & $2.85^{\mathrm{Bb}}$ & 0.029 \\
\hline 77 & 5.69 & 5.59 & 5.64 & 5.53 & 0.055 \\
\hline 112 & 11.19 & 11.08 & 10.91 & 10.87 & 0.098 \\
\hline 154 & 17.02 & 16.63 & 16.86 & 16.59 & 0.169 \\
\hline \multicolumn{6}{|l|}{ Feed intake, $\mathrm{kg} / \mathrm{kg}$} \\
\hline days: $1-35$ & 1.76 & 1.76 & 1.76 & 1.78 & 0.023 \\
\hline $1-56$ & 1.91 & 1.92 & 1.92 & 1.92 & 0.012 \\
\hline $1-77$ & 2.07 & 2.09 & 2.06 & 2.07 & 0.024 \\
\hline $1-112$ & 2.38 & 2.38 & 2.40 & 2.42 & 0.036 \\
\hline $1-154$ & 2.82 & 2.89 & 2.90 & 2.93 & 0.026 \\
\hline \multirow{2}{*}{$\begin{array}{c}\text { Relative cost of feed } \\
\text { per kg BW, \% }\end{array}$} & 100 & 96.2 & 88.9 & 91.5 & - \\
\hline & 104 & 100 & 92.5 & 95.1 & - \\
\hline \multicolumn{6}{|l|}{ Losses, $\%$} \\
\hline 1-154 days & 7.0 & 2.6 & 3.5 & 7.0 & - \\
\hline WEO & 321 & 310 & 295 & 290 & 9.904 \\
\hline
\end{tabular}

$\mathrm{a}, \mathrm{b}-\mathrm{P} \leqslant 0.05$

$\Lambda, \mathrm{B}-\mathrm{P} \leqslant 0.01$

Loss of birds (Table 4) during the 154-day fattening period was small (2.6-3.5\%; groups 1 and 2, respectively) and up to $7.0 \%$ (control and group 3). Losses were mainly due to mortality (poor health of chicks and inflammation of the yolk sac), and, to a lesser degree, to culling (cachexia and leg deformitics).

The Fattening Efficiency Index (FEI) for the entire period of fattening birds fed the wheat-maize mixtures (control group) was higher by $3.5-10.5 \%$ than for birds fed the triticale-barley mixtures (groups 1 to 3 ).

TABELA 5

Indices of slaughter analysis, \% of body weight

\begin{tabular}{|c|c|c|c|c|c|}
\hline \multirow{2}{*}{ Indices } & \multicolumn{4}{|c|}{ Groups } & \multirow{2}{*}{ SEM } \\
\hline & control & 1 & 2 & 3 & \\
\hline Dressing percentage & 83.4 & 83.8 & 83.3 & 83.8 & 0.332 \\
\hline Giblets & $1.7^{\mathrm{bo}}$ & $1.6^{\text {A.s }}$ & $1.8^{\mathrm{Rh}}$ & $1.6^{a c}$ & 0.052 \\
\hline Breast muscles & 26.4 & 26.1 & 25.3 & 25.9 & 0.599 \\
\hline Leg muscles & 19.2 & 19.3 & 19.7 & 20.3 & 0.506 \\
\hline Abdominal fat & 1.3 & 1.3 & 1.3 & 0.9 & 0.141 \\
\hline
\end{tabular}

a, b, c - P $\leqslant 0.05$

A. B $-P \leqslant 0.01$ 
The results of carcass dressing analysis and partial dissection of 22-week-old tom turkeys (Table 5) did not show distinct differences among the feeding regimens used; with respect to carcass dressing percentage $(83.4-83.8 \%)$, the breast meat content $(25.3-26.4 \%)$, thigh muscle $(19.2-20.3 \%)$ or intermuscular fat content $(0.9-1.3 \%)$.

\section{CONCLUSIONS}

Balanced feed mixtures containing a considerable proportion of triticale (up to $46.8 \%$ ) and barley (up to $35.0 \%$ ) had a similar nutritional value as wheat-maize mixtures.

A similar energy value of mixtures 1,2 , and 3 was found in the balance experiment, and as well, similar final body weights were obtained. The similarity in feed utilization for weight gain and carcass dressing confirm the assumption that the addition of enzymatic preparations can increased energy value $\left(\mathrm{AMF}_{\mathrm{v}}\right)$ of cereal feeds by $6-10 \%$.

Feed mixtures supplemented with enzyme preparations were more economical in comparison with the control triticale-barley (by $5.0 \%-7.5 \%$ ) and wheat-maize (by $8.5 \%-11.0 \%$ ) feeds.

\section{REFERENCES}

$\Lambda 1$ Bustary Z., 1996. The effect of pelleting an enzyme-supplemented barley-based broiler diet. Anim. Feed Sci. Technol. 58, 283-288

Brencs A., Smith M., Guenter W., Marquardt R.R.,1993. Effect of enzyme supplementation on the performance and digestive tract size of broiler chickens fed wheat and barley- based diets. Poultry Sci. 72, 1731-1739

Choct M., 1996. The role of feed enzymes in animal nutrition towards 2000. Proceedings of XX World's Poultry Congress, New Delhi (India), Vol. II, pp. 125-133

Classen H.I., 1996. Cereal grain starch and exogenous enzymes in poultry diets. Anim. Feed Sci. Technol. 62, 21-27

Ekman P., Emanuelson M.. Bransson A.. 1949. Investigations concerning the digestibility of protein in poultry. Ann. Royal Agr.Col. of Sweden, 16, 749-754

European Táble of Energy Values for Poultry Feedstuffs, 1989. WPSA, Spelderholt Centrc for Poultry Research and Extension, Beekbergen, The Netherlands

Faruga $\Lambda$., Jankowski J., 1996. Turkeys - Brecding and Management (in Polish). PWRil, Warszawa Faruga A., Mikulski D., Kozlowski K., Mikulska M., 1996. Effect of use of enzyme preparations on fattening performances of broilers. 4. Tagung Schweine- und Gefülgelernährung, Halle (Germany). pp. 301-304

Ferket PR., 1993. Practical usc of feed enzymes for turkeys and broilers. J. Appl. Poultry Res. 2, 75-81

Jcroch H., Danicke S., Brufau J., 1995. The influence of enzyme preparations on the nutritional value of ccrcals for poultry. J. Anim. Feed Sci. 4, 263-285 
Kaoma C., Bláha J., Hcger J., Škarková L., 1996. Estimation of the level of enzyme preparation required to obtain optimum nutrient utilization and growth performance in young broiler chick fed on barley diets (in Czech). Živ. Výroba, 41, 9-14

Marquardt R.R., Brenes A., Zhang Z., Boros D., 1996. Use of enzymes to improve nutrient availability in poultry feedstuffs. Anim. Feed Sci. Technol. 60, 321-330

Mohammed A.H., 1995. Barley varieties, enzyme supplementation, and broiler performance. J. Appl. Poultry Res. 4, 230-234

Muramatsu T., Morishita T., Niwa N., Furuse M., Okumura J., 1992. Growth improvement by a fiber - degrading enzyme supplement in the chicken. Anim. Sci. Technol. 63, 368-378

Nutrient Requirements of Poultry, 1993. Nutritive Value of Feeds (in Polish). 2nd Edition. The Kielanowski Institute of Animal Physiology and Nutrition (Editor), Jabłonna

Richter G., Müller A., 1995. Lohnt sich der Finsatz von Enzymen in der Putenmast? Mischfutter 132, $601-602$

Rotter B.A., Friesen O.D., Guenter W., Marquardt R.R., 1990. Influence of enzyme supplementation on the bioavailable energy of barley. Poultry Sci. 69, 1174-1181

Salobir 1., Struklec M., Hergouth S., Malensek A., Bogdanic C., 1994. The influence of the enzyme preparation Polizym $\mathbf{R}$ on the apparent digestibility and energy value of broiler diets based on barley and wheat. Krmiva, 36, 107-111

Soest van P.J., Wine R.H., 1967. Use of detergents in the analysis of fibrous feed. IV. Determination of plant cell-wall constituents. J.Assoc. Off. Anal. Chem. 50, 50-55

\section{STRESZCZENIE}

\section{Wpływ uzupelniania enzymami mieszanki pszenżytnio-jęczmiennej na wyniki odchowu indyków}

456 jednodniowych indorow BUT-9, podzielonych na 4 grupy (3 powtórzenia x 38 sztuk w kazdej grupie) odchowywano do wieku 154 dni. Grupę kontrolna ływiono mieszanką pszenno-kukurydzianą, w mieszankach doświadczalnych zastąpiono te zboża pszenżytem i jęczmieniem. Mieszankę l skarmiano bcz dodatku enzymów, do mieszanek 2 i 3 wprowadzono dwa różne preparaty enzymatyczne. Do mieszanek uzupcłnionych enzymami dodawano mniej oleju sojowego, zakładając. że na skułek dodatku cnzymów AME $E_{\wedge}$ pszenżyta i pszenicy może zwiẹkszyć się o 6\%, jęczmienia o $10 \%$.

Masa ciała oraz wskaźniki wykorzystania paszy, strawność składników pokarmowych i wydajność poubojowa indyków były we wszystkich grupach zbliżone. Mieszanki z udziałem preparatów enzymatycznych były się bardziej efektywne ekonomicznie w porównaniu z kontrolnymi mieszankami ps\%enzytnio-jęczmiennymi (o 5.0-7.5 \%) i ps\%enno-kukurydzianymi (o 8.5-11.0\%). 